\title{
Cooperation in Creating Innovation in Polish Small and Medium-Sized Enterprises in the Light of Empirical Studies
}

- Zastempowski Maciej, Przybylska Natalia

\begin{abstract}
Nowadays, sources of competitive advantage and economic development are sought in the sphere of innovation. They are at the centre of interest of representatives of the world of politics, science, and business. Moreover, they have been incorporated into governmental and international strategic development programmes. This article attempts to characterize and evaluate cooperation in creating innovation in small and medium-sized enterprises in Poland. Empirical research, a fragment of which is presented in this article, was conducted at the turn of March and April 2015 on a representative sample of Polish small and medium-sized enterprises. The subject of the analysis was business innovation expressed through the indicators of innovation and frequency of cooperation with different entities from the business environment to create new solutions, as well as forms of business innovation. The evaluation of the existing dependence was performed on the basis of the estimation results of the logit model. The objective of this study was to identify key factors related to cooperation and their impact on the innovativeness of Polish companies, using the tools of econometric analysis. The article presents a contemporary approach to managing innovative activity - open innovation, which is both widely reported and reflected in the results of research conducted. The logit model that was developed also indicates that companies that are open to cooperation with customers and academic institutions of the Polish Academy of Sciences (PAN) and are members of clusters are more likely to implement innovations of a radical nature.
\end{abstract}

Keywords: innovation, cooperation, open innovation, SMEs, interorganizational relations JEL Classification: D22, D83, O30

\section{INTRODUCTION}

The contemporary economic reality is burdened with multiple linkages and interdependencies that occur between all entities. The growing impact of globalization and the rapid pace of technological advances are contributing to the development of new types of linkages between the world's economies.

The ongoing international multi-layered ICT revolution is contributing to the spread of information, knowledge, and innovation on an unprecedented scale. In the era of the network society, the growing intensification of global communications, and virtualization of life, tremendous changes are taking place in all aspects of human activity (Prandecki, Śmietanko, Hacaga, \& Kazanecki, 2015). The omnipresent social, political, and economic changes allow increasingly efficient and cheaper production of goods and supply of services. On the one hand, these con- 
ditions create countless opportunities; on the other hand, however, they lead to great threats faced by entrepreneurs. The surroundings referred to as turbulent verify entities that are able to meet the growing needs. The contemporary changeable functioning conditions are conducive to smaller entities which are more flexible, and therefore are able to adapt more quickly to changes in the environment (Piasecki, 2001).

Small and medium-sized enterprises (SMEs) are called a stimulator of economic development, and their functioning is a manifestation of societal entrepreneurship. A thesis formulated many years ago by Schumpeter explains the role and meaning of the existence of SMEs. Both the theory of 'a creative entrepreneur' and the theory of 'creative destruction' assume that economic development could not happen if it were not for the constant creation of new businesses that build new quality (Schumpeter, 1995).

An innovative enterprise is the driving force in the creation of new management standards, relating both to the enterprise and its surroundings. The activity of such companies is based on the continuous generation of new ideas that will have a significant impact on the development of the company (Białon, 2010). Innovation is a desirable feature of contemporary enterprises and seems to be a response to the constantly changing dependences and conditions for building competitiveness. The escalation of needs in terms of effectiveness, speed, and delivering quality of products and services directs entrepreneurs towards developing key competences and opening up to interorganizational cooperation with a view to obtaining external sources which will complement the company's capital (Downe, 2012). Studying the dependencies that exist between company innovation and inter-organizational cooperation is intended to give an understanding of the occurring patterns, sources, and implications of purposeful relationships. In this paper the emphasis is laid on the frequency and forms of cooperation with specific entities from the external environment - both domestic and foreign ones. The results in this area are presented with a rate of innovation that takes into account their nature and type, and which was developed on the basis of Tidd and Bessant's 4Ps of innovation. With a view to identifying key factors related to cooperation and its impact on the innovativeness of Polish companies, the logit model was applied.

\section{THEORETICAL BACKGROUND}

\subsection{Defining innovation}

Activity aimed at maintaining permanent development is a characteristic of the enterprise of the future. Studying their innovativeness allows the activities conducted by them to be reviewed and assessed. It is essential in this respect to determine what this innovation is and how to stimulate it.

According to Poznańska, innovation can be understood as a result of the potential for innovation and of resistance to change, which is a manifestation of attitudes shown in the organization's internal and external environment. Resources and skills owned by the company, as well as the environmental conditions, can both promote and inhibit innovation activity. The development of innovation includes both the effort of people and the capital necessary to develop and implement new processes or products (Poznańska, 1998). The innovative potential is a combination of resources that allow the efficient creation and implementation of changes (Zastempowski, 2014). 
The pace of the creation and commercialization of new goods and services is the result of companies' ability to accurately identify or create the needs of the target group and to meet them. Innovations are perceived as every change creating a new quality in the economic or social sense. Their manifestation is an increase in the utility of both products and services, as well as in management systems and processes. The effect of innovation is also visible in the improvement of the rationality of management, better interpersonal communication, and in the overall improvement in the quality of work and private lives (Janczewska, 2011). At present, the definition of innovation and its measurement are being widely discussed. The common denominator is the reference of the concept to some change in practices, facilities, organizational structure, or processes which stems from the innovative approach and skilful commercialization (Grandstrand, 1999).

One of the basic concepts of innovation might be the one presented in the Oslo Manual handbook, where four basic types of innovations are distinguished: marketing, organizational, product, and process (OECD \& Eurostat, 2005). The first two are classified as non-technological innovations, the other two as technological innovations. Figure 1 overviews the constructs. In the past, the focus was on technological innovations. However, later on, non-technological innovations started to grow in importance and nowadays they play an increasingly important role in business entities of developed economies. The figure presented below illustrates the relationships existing between all types of innovations. The conducted research carried out in Germany in 2007 (CIS 2007) indicates the existence of synergies due to the coordination between them. For example, implementing marketing innovations increases the organization's ability to create new products and services in the form of individualized offer that allows a comprehensive satisfaction of customer needs and contributes significantly to the success of technological innovations. Moreover, these innovations help companies reposition the brand, stretch the conducted activities to new fields of business, and change the form of distribution or directly contribute to increasing buyers' satisfaction, which ultimately impacts the improvement of market results achieved by enterprises (Schubert, 2010).

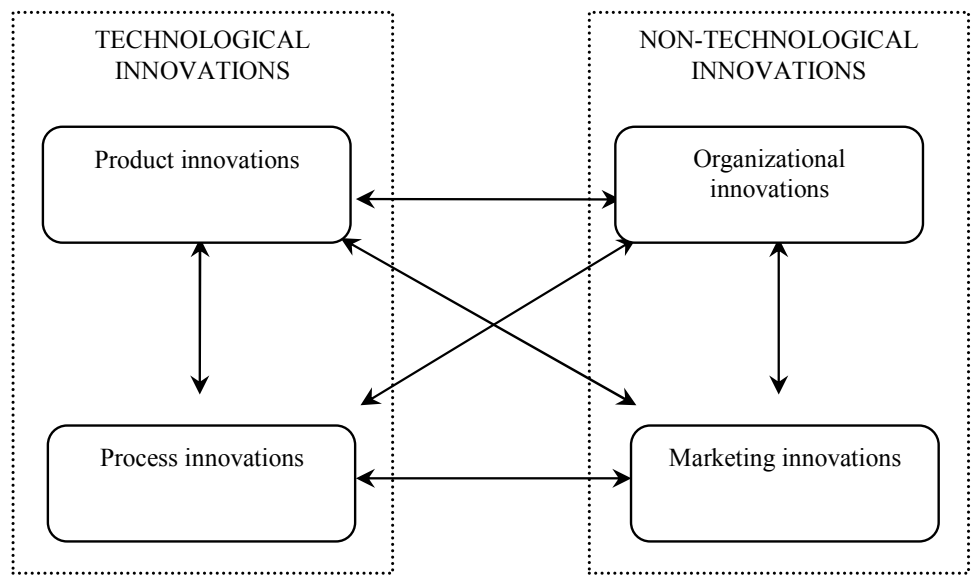

Fig. 1 - Types of innovations and occurring interdependencies (Source: Bigliardi \& Dormino, 2009) 
An innovative enterprise is one that in practice applies new product, process, organizational, and marketing solutions. Such companies are referred to as smart, they gain recognition in their environment due to the high level of modernity and competitiveness. It should be emphasized that an innovation is not a discovery or research on new solutions, i.e., inventions which are merely a chance for an innovation to emerge. Only using these solutions in practice and their direct impact on the company or economy make them innovations (Strzelecka, 2011).

The concept of innovation can be defined in various ways, one of them is an example of the 4Ps model which consists of four forms of change:

- product (services) innovation

- process innovation (changes in the way in which products are manufactured)

- position innovation (changes in the user's perception of goods and services)

- paradigm innovation (changes in the fundamental principles of the enterprise functioning (see fig. 2).

Similar to the above scheme, the following model, though it distinguishes other four types of innovations, indicates the simultaneous occurrence and a kind of overlap of various forms. An example may be a new car model that requires creating new processes related to manufacturing technology. In this case, a change occurs both within products and processes. Innovations can also be considered in terms of their degree of novelty - ranging from gradual to radical (Tidd \& Bessant, 2013). This model was used to create an innovation indicator which will be discussed further on in this article.

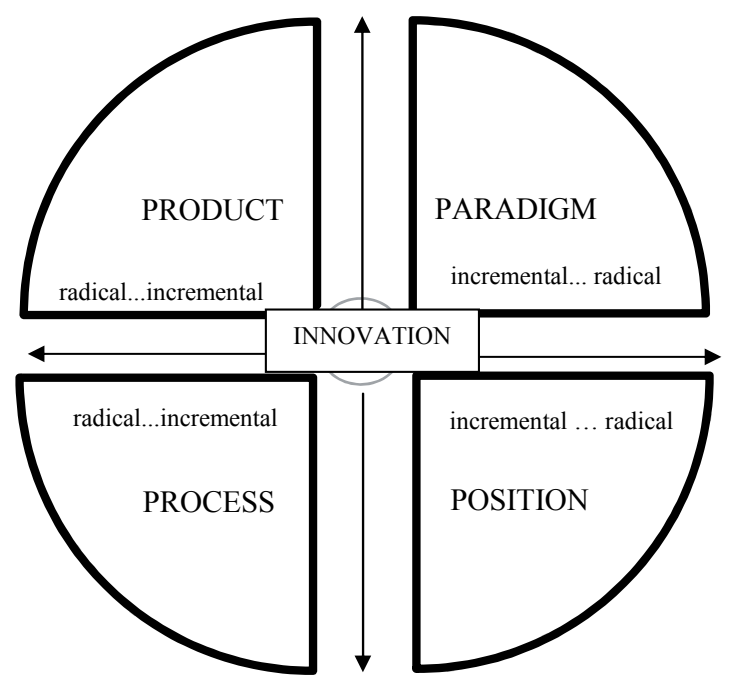

Fig. 2 - Model 4 Ps of innovation (Source: Bessant \& Tidd, 2013)

Analysing the categories of innovation, depending on the novelty of the implemented changes, the following two polarised poles are characterized most frequently: 
- incremental innovations - gradual improvements, improving what has been done so far,

- breakthrough innovations - radical changes, doing things in an entirely new way.

Breakthrough innovations are marked with a disruptive change, which somehow finishes a certain past period and the activities performed up to the moment. These innovations are rare, it is estimated that a successful change of this type in a certain area happens once every 5-10 years. These innovations require much more time to occur, it happens that the market is not ready for this change and, therefore, the commercialization stage may be prolonged, which can be very dangerous for the company-innovator (Norman \& Verganti, 2014). Looking at the degree of novelty through the prism of cooperation in the field of innovation, many authors concur as to the fact that creating new innovations together with customers does not lead to a breakthrough innovation (Christensen, 1997; Norman \& Verganti, 2014; Van Der Bijl Brouwer \& Dorst, 2014). The analysis of the relationship between the degree of novelty and the broadly understood cooperation in the innovation process are the focus of this study.

\subsection{The essence of cooperation for innovation}

Innovative companies are managed in a way that allows more flexible and dynamic adaptation to changing environmental conditions, or taking action preceding changes, which allows determining the rules of competition. Creating and developing networks of innovation allows facing reality through undertaking the following actions:

- maintaining solid relationships with customers, suppliers, business partners forming alliances, or competitors enables the entity to respond quickly to the stimuli coming from the market which can be crucial in an accurate evaluation of the market risks and opportunities,

- making regular efforts with a view to establishing new relationships that may be a motive for creating new products or services,

- reducing the time needed to reach the sought resource held by another organization,

- shortening the time needed to inform business partners and markets about the creation of new products, services, and about the existing implementation capacities of the organization,

- continuous monitoring of holding relationships, both those initiated by the organization as well as potential ones which the organization could initiate,

- flexible allocation of resources, which will allow a rapid response to the need for modification in the scope of products manufactured or services rendered,

- conscious development of innovative organizational culture that appreciates changes, continuing education, assimilation of new members, managing diversity, as well as tolerates mistakes, and appreciates learning from mistakes made,

- an organizational strategy should include criteria defining a procedure for the permanent penetration of the environment with a view to seeking favourable offers, joint ventures, and possible alliances (Perechuda \& Chomiak-Orsa, 2013).

Entrepreneurs should create the so-called innovation space that would allow responding better to the needs of the environment, due to the conditions that facilitate a rapid transfer of knowl- 
edge, both within the organization and within its environment. The progressive socialization of knowledge determines the need to acquire knowledge through relationships with those who possess it (Jemielniak \& Koźmiński, 2008).

Due to the dynamic development of the network, many unprecedented forms of cooperation have been developed. The phenomenon of co-creation can be characterized through the prism of an active client that is referred to as the prosumer, millions of members in virtual communities cooperating and assisting each other remotely (Wikinomics), or of anonymous crowds generating new ideas and solutions (crowdsourcing). These types of activities have a real impact on the way of the functioning of contemporary business entities, which, as a matter of fact, have no other way to continue their development but to be open to the newly created reality (Tapscott \& Williams 2008, Gansky, 2010).

The concept of cooperation, namely, the creation of interorganizational linkages and of different kinds of relationships in order to create a competitive advantage, such as, for instance, innovation networks, is not a novelty. However, the variety of forms of cooperation makes it an area that is difficult to organize (Latusek-Jurczak, 2014). A new approach in the field of coopetition is the combination of the two directions of the transfer of knowledge in the form of its external acquisition and use, and sharing it outside the organization, thus ensuring its free flow. The open innovation model is based on the use of purposive inflows and outflows of knowledge (Chesbrough, 2006). This concept is characterized by a quest for iterative knowledge originating from various sources, such as suppliers, customers, universities, research laboratories, consortia, consultants, start-ups, business support organizations, or competitors (Fasnacht, 2009).

Open innovation processes merge internal and external ideas in all sorts of platforms, structures and systems applied in business models. The strategic advantage used to be built by means of internal R\&D. At present, dynamically developing markets, short product life cycles, increased mobility of workers, or a growing role of business-surrounding institutions contribute to the decline in the efficiency of the old research and development processes. Enterprises that are focused internally in an excessive way can overlook a lot of external opportunities. The open innovation model is composed of three major innovative processes (see fig. 3). Processes within the organization referred to as directed inwardly ('outside-in') are actions undertaken with external entities, directed outwardly ('inside-out') ones, in turn, are the various types of knowledge sharing, and the coupled process is characterized by a two-way flow. The combination of operations should be tailored to the needs of the entity, thus creating its business model (Lameras, 2012). 


\begin{tabular}{|c|c|c|}
\hline Outside-in & Coupled process & Inside-out \\
\hline | & 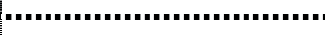 & тантв \\
\hline - $\quad$ Customers & - $\quad$ Absorptive capacity & Spin Out \\
\hline - Universities and & - Innovation & - $\quad$ Out-Licensing \\
\hline Research Institution & communities & Partner \\
\hline - Consultants & - $\quad$ Crowdsourcing & - $\quad$ Franchising \\
\hline - $\quad$ Suppliers & - $\quad$ Clustering & - $\quad$ Start-ups \\
\hline $\begin{array}{ll}\text { - } & \text { Competitors } \\
& \text { (Co-opetition) }\end{array}$ & & - $\quad$ Spin Off \\
\hline
\end{tabular}

Fig. 3 - Pillars of open innovation model (Source: Lameras, Hendrix, Lengyel et al., 2012)

The open innovation model assumes that valuable innovative solutions can be found everywhere. The results of external R\&D work and cooperation with entities from the company's environment can create a significant value for the company and its customers. It is extremely important to develop the optimal business model corresponding to the needs of a particular organization. Best results are achieved when internal and external innovative ideas are combined. The essence of the open innovation model is both gaining knowledge from the outside and using outside the company technologies or knowledge that are not strategic from the point of view of the organization, but, when expanded beyond organizational boundaries, has a chance to provide benefits. Providing other entities with unused solutions in the form of patents or licenses, the company has the opportunity to reap the tangible benefits; what is more - the developed knowledge will be used in practice, therefore, it will not be wasted. In many cases the carrier of innovation are the company's employees, who are starting their own businesses in the form of start-up or spinoff companies. The model in question is successfully applied in many companies, such as, for instance, P\&G, Philips, or Nokia.

The concept of open innovation also creates an opportunity for smaller entities. New forms of cooperation between industry and universities, or organizations of the business environment, the so-called innovation networks - such as, for instance, clustering, are increasingly important (Ebersberger, Sverre, Iversen, et al, 2011; Mytelka \&Farinelli, 2000). Clusters play an important role in learning by cooperation. Organisations present in a cluster can be more innovative due to direct observation of the suppliers, the possibility of using the collective knowledge, information, and due to network effects based on social interactions (Lazoi, Ceci, Corallo \& Secundo, 2011).

Currently, the EU-funded projects within the Operational Programme Intelligent Development (OP ID) in the areas identified as intelligent specializations will be favoured in the process of selecting projects for support. Intelligent specializations (or regional specializations) are a new instrument of the European Union which requires the regions of the Member States to choose those areas in which they want to specialize and improve competitiveness. Therefore, it is important to focus on improving the coordination of entities operating in the area, through technology development and implementation of innovative solutions. The development of enterprises 
is shaped by the specialization of economic activity, as well as by the transfer and dissemination of knowledge (Dorożyński, 2013). The variety of possibilities of using internal and external resources, which are characterized by different effectiveness and usefulness, may decide about the advantage of the economic subject, if only it is able to acquire, combine and use them for specific purposes (Tidd \& Bessant, 2013).

The development of the society referred to as innovative and informational, or learning society, plays an increasingly important role in innovative activity. A growing number of prosumers, who are not only the final recipients of goods and services but also participate actively in the creation of new products, affects significantly the activity of economic entities (Zadura-Lichota, 2013).

Research into the issues of cooperation and innovation activities is also conducted by PARP within the framework of an international project 'Global Entrepreneurship Monitor' (GEM). The results indicate that the tendency to cooperate increases along with economic development. Other studies also highlight the relationship between cooperation and the results obtained from the innovation performance - companies that in the past three years implemented innovations undertake cooperation more frequently than those which are not innovative (Zadura-Lichota, 2015).

A broad spectrum of research conducted on innovation should take into account the aspect of cooperation, which is an integral part of the activities of enterprises operating in a knowledgebased economy. Business strategies should be developed with the consideration of the relational forms, reorientation towards the consumer, and undertaking cooperation in the innovation process (Pittaway, Robertson, Munir, Denyer \& Neely, 2004; Weaver, 2008).

\section{LOGIT MODEL OF INNOVATION IN POLISH SMALL AND MEDIUM-SIZED ENTERPRISES}

\subsection{Research methods}

The empirical studies, part of which was presented in this study, were conducted in 2015 within a research project titled - Innovativeness of small and medium-sized enterprises under the economic crisis - conditions, trends and models, the project was financed by the National Science Centre with funds granted pursuant to Decision No DEC-2013/09/B/HS4/01971 The research sample covered 250 subjects and its representativeness was based on the following criteria: company size, type of activity by sections and NACE classification, the seat of the company (taking into account the area of all provinces) and the period of operating on the market not shorter than 5 years. The survey was conducted using CAPI (Computer Assisted Personal Interviewing).

Among the surveyed companies, $83.2 \%$ were innovatively active, i.e., implemented at least one innovation in the time period 2012-2014. For this group of companies an innovation indicator was created, based on a question concerning the percentage share of a given type of innovation - paradigm, product, process, and position, and about the nature of the implemented change measured on a five-point scale (1 - small, 5 - radical), according to the following formula: 


$$
\mathrm{W}_{\mathrm{i}}=\frac{\left(\mathrm{U}_{\mathrm{P} 1} * \mathrm{~S}_{\mathrm{P} 1}+\mathrm{U}_{\mathrm{P} 2} * \mathrm{~S}_{\mathrm{P} 2}+\mathrm{U}_{\mathrm{P} 3} * \mathrm{~S}_{\mathrm{P} 3}+\mathrm{U}_{\mathrm{P} 4} * \mathrm{~S}_{\mathrm{P} 4}\right)}{100}
$$

where:

$\mathrm{W}_{\mathrm{i}}$ - the innovation indicator

$\mathrm{U}_{\mathrm{p} 1}$ - the share of the paradigm innovation in the total of innovations [\%]

$\mathrm{S}_{\mathrm{p} 1}-$ the scale of the implemented paradigm innovation [1-5]

$\mathrm{U}_{\mathrm{p} 2}$ - the share of the product innovation in the total of innovations [\%]

$\mathrm{S}_{\mathrm{p} 2}$ - the scale of the implemented product innovation [1-5]

$\mathrm{U}_{\mathrm{p} 3}$ - the share of the process innovation in the total of innovations [\%]

$\mathrm{S}_{\mathrm{p} 3}$ - the scale of the implemented process innovation [1-5]

$\mathrm{U}_{\mathrm{p} 4}$ - the share of the position innovation in the total of innovations [\%]

$\mathrm{S}_{\mathrm{p} 4}$ - the scale of the implemented position innovation [1-5]

According to the above formula, the innovation indicator took the values 1-5. For further analysis using a logit model it was necessary to transform the value of the innovation indicator into the dichotomous variable. This was done according to the median value which amounted to 3.34 . Thus, companies implementing innovations on a small and large scale were differentiated. The dependent variable, therefore, assumes the value of zero or one:

$y=1$, when a company implements innovations on a large scale,

$\mathrm{y}=0$, when a company implements innovations on a small scale.

The indicator transformed in that way could be used in a binomial logit model. The direct use of the innovation indicator was not correct from the point of view of statistics and econometrics, since processes of limited variables for the values that are not natural numbers cannot be modelled (Gruszczyński, 2012).

The model describes the influence of the independent variables $X_{1}, \ldots, X_{k}$ on the dichotomous variable $\mathrm{Y}$. The logit function took the following form:

$$
f(z)=e^{z} /\left(1+e^{z}\right)=1 /\left(1+e^{-z}\right) \quad, z \text { set membership } R \text {. }
$$

where: $Z=\alpha_{0}+\alpha_{1} X_{1}+\alpha_{2} X_{2}+\ldots+\alpha_{k} X_{k}$.

The function takes a value from the range (0;1). The logit model for dichotomous variable $\mathrm{Y}$ is determined by the following dependence:

$$
P\left(Y=\frac{1}{X_{1}, \ldots, X_{k}}\right)=\frac{e^{\alpha_{0}+\propto_{1} X_{1}+\cdots+\propto_{k} X_{k}}}{1+e^{\alpha_{0}+\propto_{1} X_{1}+\cdots+\alpha_{k} X_{k}}}
$$

where:

$a_{0}, a_{1}, \ldots, a_{k}$ are the coefficients of the logit model, $X_{1}, \ldots, X_{k}$ are independent qualitative or quantitative variables (Machowska-Szewczyk \& Sompolska-Rzechuła, 2010). 
The likelihood of the occurrence of an event based on the frequency of empirical observations is modelled for configuring specific independent features. The parameters are estimated by means of a maximum likelihood method, looking for parameters $\alpha_{j}$ values that maximize the reliability of the test. The interpretation of parameter estimations is the following:

- when the result obtained from the sample test indicates that $\alpha_{j}>0$, it is considered that the factor described by the independent variable $X j$ acts as a stimulant for the likelihood of the occurrence of the tested event, with a controlled impact of other variables included in the equation;

- when the result obtained from the sample test indicates that $\alpha_{j}<0$, it is considered that the factor described by the independent variable $X_{j}$ diminishes the likelihood of the occurrence of the tested event, with a controlled impact of other variables included in the equation;

- when the result obtained from the sample test indicates that $\alpha_{j}=0$, it is considered that the factor described by the independent variable $X_{j}$ has no effect on the likelihood of the occurrence of the tested event, with a controlled impact of other variables included in the equation (Rószkiewicz, 2002).

The estimated logit model explains the likelihood of the implementation of a large scale innovation, depending on explanatory variables of a qualitative nature. The significance of the variables was examined with the use of a posteriori method at the level of $\alpha=0.05$.

The adopted model variables had the characteristics of the type of activity related to the introduction of new or improved products or processes, as well as entities which cooperated most while developing new solutions. Also, the size of the market on which new products were being introduced was considered. The model hypothesis comprised 36 factors. A detailed description of the explanatory variables is contained in a table annexed (see tab. 1).

After estimating the parameters, we were able to determine the theoretical values of the variable Y according to the standard forecasting principle (Machowska-Szewczyk \& SompolskaRzechuła, 2010):

$\hat{y}_{\mathrm{i}}=\left\{\begin{array}{l}1, \text { when } 0.5<\pi \leq 1 \\ 0, \text { when } 0<\pi \leq 0.5\end{array}\right.$

One can then evaluate the correctness of the estimated model by counting both correctly and incorrectly classified cases (see tab. 2).

Tab. 2 - The accuracy of cases classification. Source: Machowska-Szewczyk \& SompolskaRzechuła, 2010.

\begin{tabular}{|l|l|l|}
\hline \multirow{2}{*}{ Observed } & \multicolumn{2}{|c|}{ Expected values } \\
\hline & $\hat{\mathrm{y}}_{\mathrm{i}}=1$ & $\hat{\mathrm{y}}_{\mathrm{i}}=0$ \\
\hline $\mathrm{y}_{\mathrm{i}}=1$ & $\mathrm{n}_{11}$ & $\mathrm{n}_{12}$ \\
\hline $\mathrm{y}_{\mathrm{i}}=0$ & $\mathrm{n}_{21}$ & $\mathrm{n}_{22}$ \\
\hline
\end{tabular}


The evaluation of the model fit to the empirical data is possible through the use of the measure of pseudo- $\mathrm{R}^{2}$ obtained according to the following formula:

pseudo $\mathrm{R}^{2}=\left(n_{11}+n_{22}\right) /\left(n_{11}+n_{12}+n_{21}+n_{22}\right)$

It takes a value between $[0,1]$, the closer it is to 1 , the better the fit of the model. When the value exceeds 0.5 , it is assumed that the classification is better than random one, thereby $\mathrm{R}^{2}$ is the percentage of cases correctly classified (Gruszczyński, 2000).

Another statistics used to test classification significance is $\chi^{2}$, the higher value it takes, the stronger grounds to accept the results as significant. It is calculated according to the formula:

$$
\chi^{2}=-\left(n-\frac{k+p}{2}-1\right) \ln \left(\frac{1}{1+\lambda}\right)
$$

where: $n$ - the number of observations; $k$ - the number of groups, $\mathrm{k}=2, p$ - the number of diagnostic variables; $\lambda$ - the value of Wilks' $\lambda$ statistics

The point of reference in assessing the value of $\chi^{2}$ is the number read from the distribution tables for chi-square when $\alpha=0,05$ and $\mathrm{v}=\mathrm{p}$. When the calculated value exceeds the one read from the tables, the classification results can be considered statistically significant (Rószkiewicz, 2002).

\subsection{Results and discussion}

The evaluations of the estimated model of the innovation of Polish small and medium-sized enterprises are shown in the table below (see Tab. 3):

Tab. 3 - Evaluations of the parameters of the logit model. Source: own

\begin{tabular}{|l|l|c|c|c|}
\hline \multicolumn{2}{|c|}{ Described variable } & Parameter & Standard error & $\begin{array}{c}\text { Statistics } \\
z\end{array}$ \\
\hline & Constant & -4.11438 & 1.2089 & -3.929 \\
\hline X4 & customers & 0.437923 & 0.149827 & 3.107 \\
\hline X7 & jedn_PAN & 0.515301 & 0.147476 & 3.171 \\
\hline X17 & cluster & 1.60889 & 0.576109 & 1.755 \\
\hline X20 & wsp_proj & -0.942006 & 0.433415 & -1.925 \\
\hline X24 & Eur & 1.48503 & 0.424704 & 1.673 \\
\hline X36 & inne_test & -1.32736 & 0.424527 & -2.602 \\
\hline
\end{tabular}

Therefore, the estimated model is of the following form:

$$
\hat{p}=P(y=1)=\frac{e^{-4,114+0,438 x_{4}+0,515 x_{7}+1,609 x_{17}-0,942 x_{20}+1,485 x_{24}-1,327 x_{36}}}{1+e^{-4,114+0,438 x_{4}+0,515 x_{7}+1,609 x_{17}-0,942 x_{20}+1,485 x_{24}-1,327 x_{36}}}
$$


After the transformation the model can be summarized as follows:

$$
\operatorname{logit} \hat{p}=-4,114+0,438 \mathrm{x}_{4}+0,515 \mathrm{x}_{7}+1,609 \mathrm{x}_{17}-0,942 \mathrm{x}_{2} 0+1,485 \mathrm{x}_{24}-1,327 \mathrm{x}_{36}
$$

In this model there are variables with both positive and negative signs; therefore their impact on the dependent variable both stimulates and diminishes the likelihood of the implementation of large-scale innovations by small and medium-sized companies in Poland.

Out of the total of 208 enterprises 147 were correctly diagnosed in terms of their belonging to a group characterized by the implementation of innovations on a small or large scale. This means that the logit function assumes an event of the correctness of $70.7 \%$ and was found to be incorrect in 61 cases (see Tab. 4).

Tab. 4 - The accuracy of the classification of cases according to the logit model of the innovation of Polish small and medium-sized enterprises. Source: authors' own research

\begin{tabular}{|l|c|c|}
\hline Observed & \multicolumn{2}{|c|}{ Expected values } \\
\hline & $\hat{y}_{\mathrm{i}}=1$ & $\hat{\mathrm{y}}_{\mathrm{i}}=0$ \\
\hline $\mathrm{y}_{\mathrm{i}}=1$ & 77 & 27 \\
\hline $\mathrm{y}_{\mathrm{i}}=0$ & 34 & 70 \\
\hline
\end{tabular}

When the odds quotients for the $\mathrm{i}$-th variable were interpreted (assuming that all the other variables of the model remain unchanged), the following information was obtained:

- $\mathrm{e}^{0.438}=1.55$, which indicates that with more frequent cooperation with customers in the area of innovative activities, the chance to create large-scale innovations increases by $55 \%$ on average, with a controlled impact of other factors.

- $\mathrm{e}^{0.515}=1.67$, which indicates that with more frequent cooperation with the scientific institutions of PAN (the Polish Academy of Sciences) in the area of innovative activities, the chance to create large-scale innovations increases by $67 \%$ on average, with a controlled impact of other factors.

- $\mathrm{e}^{1.609}=5.003$, which indicates that if the company cooperates with other enterprises or institutions within a cluster initiative, the chance to create large-scale innovations increases by $400 \%$, with a controlled impact of other factors.

- $\mathrm{e}^{-0.942}=0.389$, which indicates that cooperation with other entities within joint projects aimed at increasing a company's innovation affects the implementation of smaller-scale innovations by $61 \%$ more frequently on average than in the case of large-scale innovations, with a controlled impact of other factors.

- $\mathrm{e}^{1.485}=4.419$, which indicates that companies introducing product innovations which were the first products of their kind in Europe are characterized by a greater likelihood of implementing large-scale innovations - on average by $342 \%$, if compared with other companies, with a controlled impact of other factors.

- $\mathrm{e}^{-1.327}=0.265$, which indicates that preparations for the introduction of new or significantly improved products or processes (feasibility studies, testing, development and improvement 
of software, instrumentation) affect the implementation of smaller-scale innovations on average by $73.5 \%$ more frequently than in the case of large-scale innovations, with a controlled impact of other factors.

On the basis of the above information, it may be concluded that within innovative activity that is conducted, implementing innovations that have the characteristics of radical changes will be stimulated as a result of establishing cooperation with customers and PAN research institutions, and through undertaking cooperation within a cluster initiative. Companies that are focused on making their product innovations the first of their kind on the European market implement innovations that are more radical in their nature. In turn, innovations that correspond to minor changes are stimulated by carrying out or commissioning external preparations for the introduction and activities related to the design, improvement, and change in the form or appearance of new or significantly improved products.

\section{CONCLUSION}

The article used data obtained from a nationwide survey conducted among small and medium-sized enterprises. On the basis of the estimated logit model, the likelihood of the impact of cooperation with external entities and the forms of innovative activities conducted on the scale of implemented innovations were determined. Contemporary trends in creating innovation through cooperation, such as demand innovations, clusters, and open innovations, are reflected in the estimated model. A positive influence on creating new solutions on a large scale is exerted by co-creating with customers, PAN research institutions, and with other institutions and enterprises within clusters.

Both progressive and radical innovations are very important. Through the study of innovation processes it will be possible to gain a better understanding of the essence, conditions, and consequences associated with innovation - their different types and degree of novelty. The formulated overall rate of innovation is a significant simplification of reality. When analysing it, one can see some interesting areas of research that need to be explored further. One of them is co-creating innovation with customers, with whom cooperation occurs most often. However, in the subject literature we may come across statements stating that such cooperation does not result in ground-breaking changes. End users do not, therefore, need to be directly involved in the designing of innovation, but human needs should be at the centre of the design process (Van Der Bijl-Brouwer \& Dorst, 2014). Equally interesting are the subjects of clusters and open innovation. What is also debatable is the issue of the measurement of innovation, which by nature is an extremely complex area and thus difficult to define.

The logit model of the innovativeness of Polish small and medium-sized enterprises indicates the relevant elements related to the activities of contemporary organizations, which, however, require further research and analysis because of the currency and high dynamics of changes. 


\section{References}

1. Bessant, J., \& Tidd, J. (2013). Innovation and entrepreneurship-second edition. Chichester: John Wiley \& Sons Ltd.

2. Białoń, L. (2010). Firma innowacyjna. In: L. Białoń (Ed.), Zarzqdzanie driałalnościa innowacyjna, 179-183. Warszawa: Placet.

3. Bigliardi, B., \& Ivo Dormio, A. (2009). An empirical investigation of innovation determinants in food machinery enterprises. European Journal of Innovation Management, 12(2), 223-242. doi:10.1108/14601060910953988

4. Chesbrough, H.W. (2006). Open Innovation: Researching a New Paradigm, New York: Oxford University Press.

5. Christensen, C. M. (1997). The innovator's dilemma: When new technologies cause great firms to fail. Boston: Harvard Business School Press.

6. Dorożyński, T. (2013). Instytucje otoczenia biznesu a rozwój przedsiębiorstw-ujęcie regionalne. Zarzqdzanie $i$ Finanse, 11(1/3), 135-150.

7. Downe, A. G., Loke, S. P., \& Sambasivan, M. (2012). Relational capital and SME collaborative strategy in the Malaysian service industry. International Journal of Services, Economics and Management, 4(2), 145-166.

8. Ebersberger, B., Herstad, S. J., Iversen, E., Kirner, E., \& Som, O. (2011). Analysis of innovation drivers and barriers in support of better policies. Economic and Market Intelligence on Innovation. Open Innovation in Europe: Effects, Determinants and Policy (Oslo: European Commission-Enterprise and Industry)

9. Fasnacht, D. (2009). Open Innovation: The New Business Paradigm. Open Innovation in the Financial Services, 87-102.

10. Gansky, L. (2010). The mesh: Why the future of business is sharing. Penguin

11. Grandstrand, O. (1999). The Economics and Management of Intellectual Property. Towards Intellectual Capitalism. Cheltenham: Edward Elgar.

12. Gruszczyński, M. (2000). Dobór zmiennych objaśniających do modelu logitowego, Przeglad Statystyczny. XLVII, 175-185.

13. Gruszczyński, M. (2012). Modele zmiennych jakościowych dwumianowych. In: M. Gruszczyński (ed.), Mikroekonometria. Modele i metody analizy danych indywidualnych (p. 80-81), Warsaw: Oficyna Wolters Kluwer business.

14. Janczewska, D. (2011). Kształtowanie łańcucha wartości innowacji firm MŚP w warunkach globalizacji. Przedsiębiorczość-Edukacja, 7, 103-115.

15. Jemielniak, D., Koźmiński, A. K. (2008). Zarz̨qqanie wiedzq. Podrecznik akademicki (p.12-21), Warszawa: Wydawnictwa Akademickie i Profesjonalne.

16. Lameras, P., Hendrix, M., Lengyel, D., de Freitas, S., \& More, B. (2012). D6. 1: Research Review on Open Innovation: Literature Review and Best Practices.

17. Latusek-Jurczak, D. (2014). Formy współpracy międzyorganizacyjnej. In: A. K. Koźmiński, D. Latusek-Jurczak (Eds.), Relacje miedzyorganizacyjne w naukach o zarzqdzaniu (pp. 59).Warsaw: Oficyna Wolters Kluwer business. 
18. Lazoi, M., Ceci, F., Corallo, A., \& Secundo, G. (2011). Collaboration in an Aerospace Smes Cluster: Innovation and ICT Dynamics. International Journal of Innovation \& Technology Management, 8(3), 393-414. doi: 10.1142/S0219877011002398

19. Machowska-Szewczyk, M., \& Sompolska-Rzechuła, A. (2010). Wykorzystanie modelu logitowego do oceny jakości życia kobiet. Metody Ilościowe w Badaniach Ekonomicznych, 2(11), 191-200.

20. Norman, D.A., Verganti, R. (2014). Incremental and radical innovation: Design research vs. technology and meaning change. Design Issues, 30 (1), 78-96. doi: 10.1162/DESI_a_00250

21. OECD, Eurostat (2005). Podrecznik Oslo, zasady gromadzenia i interpretacji danych dotyczacych innowacji (pp.19). wydanie trzecie.

22. Perechuda, K., Chomiak-Orsa, I. (2013). Znaczenie kapitatu relacyjnego we wspótcæesnych koncepcjach zarzqdzania, 4(1), 310-311. Zarządzanie i Finanse.

23. Piasecki, B. (2001). Małe i średnie przedsiębiorstwa w gospodarce narodowej. In: B. Piasecki (Ed.), Ekonomika i zarzadzanie mała firma (p. 76-78). Warszawa: PWN.

24. Pittaway, L., Robertson, M., Munir, K., Denyer, D., \& Neely, A. (2004). Networking and innovation: a systematic review of the evidence. International Journal of Management Reviens, 5-6(3-4), 137-168. doi:10.1111/j.1460-8545.2004.00101.x

25. Poznańska, K. (1998). Uwarunkowania innowacji w małych i średnich przedsiębiorstwach. ABC.

26. Prandecki, K., Śmietanko, S., Hacaga, M., \& Kazanecki, W. (2015). Rewolucja informacyjna a społeczeństwa połowy XXI wieku - punkt widzenia młodego pokolenia. In: J. Auleytner, J. Kleer (Eds.), Rewolucja informacyjna a kryzys intelektualny (pp. 204-206). Warszawa: Polska Akademia Nauk Komitet Prognoz „Polska 2000 Plus”.

27. Rószkiewicz, R. (2002). Metody ilościowe w badaniach marketingowych (pp. 173, 176, 179). Warszawa: Wydawnictwo Naukowe PWN.

28. Strzelecka, R. (2011). Innowacyjność jako czynnik rozwoju małych i średnich przedsiębiorstw w okresie spowolnienia gospodarczego. In: A. Zakrzewska-Bielawska (Ed.), Wyzwania rozwojowe malych i średnich przedsiębiorstw: Innowacje, Technologie, Kryzys, Warszawa: Difin.

29. Schumpeter, J. A. (1995). Kapitalizm. Socjalizm. Demokracja. Warszawa: Wydawnictwo Naukowe PWN.

30. Schubert, T. (2010). Marketing and organisational innovations in entrepreneurial innovation processes and their relation to market structure and firm characteristics. Review of Industrial Organization, 36(2), 189-212.

31. Tapscott, D., Williams, A. D. (2008). Wikinomia. O wspótpracy, która zmienia wszystko. Warszawa: Wydawnictwa Akademickie i Profesjonalne.

32. Weaver, R. D. (2008). Collaborative pull innovation: Origins and adoption in the new economy. Agribusiness, 24(3), 388-402

33. Van Der Bijl Brouwer, M., \& Dorst, K. (2014). How deep is deep? A four-layer model of insights into human needs for design innovation. In 9 th International Conference on Design and Emotion 2014: The Colors of Care. Universidad de los Andes. 
34. Zadura-Lichota, P. (2013). Świt innowacyjnego społeczeństwa. Trendy na najbližsze lata, PARP, Warsqawa, 2013, 118. https://www.parp. gov. pl/files/74/81/626/15959. pdf.

35. Zadura-Lichota, P. (2015). Trendy, które budują innowacyjność. In: P. Zadura-Lichota (Ed.), Innowacyjna przedsiębiorczość w Polsce. Odkryty i ukryty potencjał polskiej innowacyjności (pp. 112). Warszawa: PARP.

36. Zastempowski, M. (2014). The innovative potential of polish enterprises, AUNC Zarzquanie, 41(1).

\section{Contact information}

dr hab. Maciej Zastempowski, prof. UMK

E-mail:mz@umk.pl

Natalia Przybylska, MSc

E-mail:nataliap@doktorant.umk.pl

Nicolaus Copernicus University in Torun

Faculty of Economic Sciences and Management

ul. Gagarina 13a, 87 - 100 Toruń, Poland

\section{Appendix}

Tab. 1: Description of explanatory variables. Source: own

\begin{tabular}{|l|l|l|}
\hline WEB2.0 & X1 & The use of web 2.0 platforms (e.g., social media) in innovation activities \\
\hline $\begin{array}{l}\text { inne_ } \\
\text { przeds }\end{array}$ & X2 & The frequency of cooperation with other companies \\
\hline dost & X3 & The frequency of cooperation with suppliers \\
\hline klienci & X4 & The frequency of cooperation with customers \\
\hline konkur & X5 & The frequency of cooperation with competitors \\
\hline konsulting & X6 & The frequency of cooperation with consulting companies \\
\hline jedn_PAN & X7 & The frequency of cooperation with PAN research institutions \\
\hline instyt_bad & X8 & The frequency of cooperation with research institutions \\
\hline szk_w & X9 & The frequency of cooperation with higher education institutions \\
\hline $\begin{array}{l}\text { inne_- } \\
\text { przeds_z }\end{array}$ & X10 & The frequency of cooperation with other foreign enterprises \\
\hline dost_z & X11 & The frequency of cooperation with foreign suppliers \\
\hline klienci_z & X12 & The frequency of cooperation with foreign customers \\
\hline konkur_z & X13 & The frequency of cooperation with foreign competitors \\
\hline $\begin{array}{l}\text { konsult- } \\
\text { ing_z }\end{array}$ & X14 & The frequency of cooperation with foreign consulting companies \\
\hline
\end{tabular}




\begin{tabular}{|c|c|c|}
\hline $\begin{array}{l}\text { zagr_in- } \\
\text { styt_bad }\end{array}$ & $\mathrm{X} 15$ & The frequency of cooperation with foreign research institutions \\
\hline szk_w_z & $\mathrm{X} 16$ & The frequency of cooperation with research institutions \\
\hline klastr & $\mathrm{X} 17$ & Cooperation within cluster initiatives \\
\hline poz & $\mathrm{X} 18$ & Gaining external knowledge / ideas / technologies \\
\hline udost & $\mathrm{X} 19$ & $\begin{array}{l}\text { Sharing knowledge or technologies developed by the enterprise (e.g., a } \\
\text { license) }\end{array}$ \\
\hline Wsp_proj & $\mathrm{X} 20$ & $\begin{array}{l}\text { Joint projects implemented with external entities aimed at increasing the } \\
\text { company's innovativeness }\end{array}$ \\
\hline rynek & $\mathrm{X} 21$ & $\begin{array}{l}\text { Product innovations targeted at the market on which the company oper- } \\
\text { ates (launched on the market before the competition) }\end{array}$ \\
\hline przeds & $\mathrm{X} 22$ & $\begin{array}{l}\text { Product innovations exclusively for the company (previously introduced } \\
\text { on the market by the competition) }\end{array}$ \\
\hline kraj & $\mathrm{X} 23$ & Product innovations which were the first in the country \\
\hline Eur & $\mathrm{X} 24$ & Product innovations which were the first in Europe \\
\hline swiat & $\mathrm{X} 25$ & Product innovations which were the first in the world \\
\hline udost_proj & $\mathrm{X} 26$ & $\begin{array}{l}\text { Innovative project which was made available outside of the company / } \\
\text { developed outside the enterprise }\end{array}$ \\
\hline B+R_stale & $\mathrm{X} 27$ & $\begin{array}{l}\text { Regular research and development (R\&D) work performed in the com- } \\
\text { pany (internal) }\end{array}$ \\
\hline $\begin{array}{l}\text { B+R_do- } \\
\text { rywcze }\end{array}$ & $\mathrm{X} 28$ & $\begin{array}{l}\text { Sporadic research and development }(\mathrm{R} \& \mathrm{D}) \text { work performed in the } \\
\text { company (internal) }\end{array}$ \\
\hline B+R_zew & $\mathrm{X} 29$ & Research and development (R\&D) work acquired from outside \\
\hline masz & $\mathrm{X} 30$ & $\begin{array}{l}\text { Acquisition of high-tech machinery and equipment, means of transport, } \\
\text { tools, instruments, movables and equipment used to produce new or } \\
\text { significantly improved products or processes }\end{array}$ \\
\hline oprogr & $\mathrm{X} 31$ & $\begin{array}{l}\text { Acquisition of software related to the introduction of product and proc- } \\
\text { ess innovations }\end{array}$ \\
\hline wiedza & $\mathrm{X} 32$ & $\begin{array}{l}\text { Acquisition of knowledge from external sources (patents, unpatented } \\
\text { inventions, know-how and other types of knowledge from other } \\
\text { enterprises or organizations) for the purpose of the implementation of } \\
\text { product and process innovations }\end{array}$ \\
\hline szkol_pers & X33 & $\begin{array}{l}\text { Training of personnel (internal and external) related directly to the } \\
\text { introduction of new or significantly improved products or processes }\end{array}$ \\
\hline marketing & $\mathrm{X} 34$ & $\begin{array}{l}\text { Marketing related to the introduction of new or significantly improved } \\
\text { products (including market research and introductory advertising) }\end{array}$ \\
\hline projekt & $\mathrm{X} 35$ & $\begin{array}{l}\text { Activities related to the design, improvements and changes in the form } \\
\text { or appearance of new or significantly improved products (excluding } \\
\text { changes limited to aesthetics) }\end{array}$ \\
\hline
\end{tabular}

